\title{
Review: An integrated graphical tool for analysing impacts and services provided by livestock farming
}

\author{
J. Ryschawy ${ }^{1 a}$, B. Dumont ${ }^{2 \dagger a}$, 0. Therond ${ }^{3}$, C. Donnars ${ }^{4}$, J. Hendrickson ${ }^{5}$, M. Benoit ${ }^{2}$ and \\ M. Duru ${ }^{1}$
}

${ }^{1}$ UMR AGIR, Université de Toulouse, INRA, 31326 Castanet-Tolosan, France; ${ }^{2}$ Université Clermont Auvergne, INRA, VetAgro Sup, UMR Herbivores, 63122 SaintGenès-Champanelle, France; ${ }^{3}$ Université de Lorraine, INRA, LAE, F-68000 Colmar, France; ${ }^{4}$ DEPE, INRA, 75338 Paris, France; ${ }^{5}$ USDA-ARS, Northern Great Plains Research Laboratory, P.O. Box 459, Mandan, ND 58554-0459, USA

(Received 5 March 2018; Accepted 28 January 2019; First published online 4 March 2019)

Livestock farming is criticized for negatively impacting the environment, concerns about animal welfare and the impact of excessive meat consumption on human health. However, livestock farming provides other underappreciated and poorly communicated benefits to society in terms of employment, product quality, cultural landscapes and carbon storage by grasslands. Few attempts have been made so far to simultaneously consider the services and impacts provided by livestock production. Here, we propose an integrated graphical tool, called the 'barn' to explicitly summarize the synergies and trade-offs between services and impacts provided by livestock farming. It illustrates livestock farming interacting with its physical, economic and social environment along five interfaces: (i) Markets, (ii) Work and employment, (iii) Inputs, (iv) Environment and climate, (v) Social and cultural factors. This graphical tool was then applied by comparing two contrasting livestock production areas (high livestock density v. grasslandbased), and the dominant $\mathrm{v}$. a niche system within a crop-livestock area. We showed the barn could be used for cross-comparisons of services and impacts across livestock production areas, and for multi-level analysis of services and impacts of livestock farming within a given area. The barn graphically summarizes the ecological and socio-economic aspects of livestock farming by explicitly representing multiple services and impacts of different systems in a simple yet informative way. Information for the five interfaces relies on available quantitative assessments from the literature or data sets, and on expert-knowledge for more qualitative factors, such as social and cultural ones. The 'barn' can also inform local stakeholders or policy-makers about potential opportunities and threats to the future of livestock farming in specific production areas. It has already been used as a pedagogical tool for teaching the diversity of services and impacts of livestock systems across Europe and is currently developed as a serious game for encouraging knowledge exchange and sharing different viewpoints between stakeholders.

Keywords: ecosystem services, trade-off, sustainability, agroecology, socioecological approach

\section{Implications}

Livestock farming can provide a wide range of economic, environmental, cultural and social services at local, regional and global levels, many of which have been little quantified and poorly shared with consumers, stakeholders and policymakers. We propose an integrated graphical approach that summarizes the ecological and socio-economic aspects of livestock farming by explicitly representing the whole range of services and impacts of different systems. This graphical tool is a powerful means to highlight the diversity of livestock farming, and to share knowledge and viewpoints in search of more sustainable options for livestock farming.

\footnotetext{
${ }^{a}$ These two authors contributed equally to the research.

${ }^{\dagger}$ E-mail: bertrand.dumont@inra.fr
}

\section{Introduction}

The sustainability of livestock systems is widely debated because of their negative impact on the environment, water, soil and air quality, biodiversity, and greenhouse gas emissions, and concerns about animal welfare and excessive meat consumption on human health. Environmental impacts have been emphasized by the Food and Agricultural Organization (FAO, 2006) report 'Livestock's long shadow', and have been confirmed and clarified by the scientific literature (De Vries and de Boer, 2010; Lassaletta et al., 2014; Westhoek et al., 2015; Chaudhary and Kastner, 2016; Röös et al., 2016). However, the current evaluations have generally focussed on the negative impacts of livestock farming, with the exception of reviews and meta-analyses that stress the positive effects of grassland-based livestock farming 
(Scohier and Dumont, 2012; Rodríguez-Ortega et al., 2014) and integrated crop-livestock systems (Aguilar et al., 2015; Lemaire et al., 2015) with the subsequent benefits to ecosystem services for farmers and society. However, the multiple services provided by livestock farming systems have been rarely considered simultaneously. This applies to both the coexistence and the interactions between the services and impacts of different systems (Ryschawy et al., 2017a; Dumont et al., 2018b). Livestock effects are usually examined either by discipline (physiology, animal nutrition, etc.), dimension (environment, economy and social) or by organizational level (animal, farming system or production area), making it difficult to balance the multiple effects of different livestock production systems. One recent development does consider a broad range of indicators by analysing a 'bundle of services', that is, a set of ecosystem services that appear together repeatedly across sites and through time (Raudsepp-Hearne et al., 2010). Bundles of services (sensu lato, i.e. wider than ecosystem services) can be used to assess livestock system sustainability by simultaneously accounting for the ecological and socio-economic aspects of livestock farming across production areas. Social services include territorial vitality (e.g. employment in farms, in the agrofood industry, contribution to social cohesion) and cultural heritage (e.g. gastronomy, recreational landscape, emblematic breeds) (Plieninger et al., 2013; Beudou et al., 2017; Ryschawy et al., 2017a).

To our knowledge, there is no operational integrated tool that provides an assessment of livestock farming at the system and/or regional level, while also considering the different dimensions of livestock sustainability, and explicitly includes both impacts and services. Here, we developed a tool to analyse and represent the multiple attributes of different systems across a range of livestock production areas in a simple yet informative way. First, we review the available literature to evaluate the services and impacts provided by livestock farming. Then we show how this knowledge was used to develop a graphical tool that simultaneously accounts for the impacts and services provided by livestock farming; we apply this tool to the Tarn-Aveyron Basin, which is a region with a balance between livestock production and cash crops. Third, we apply this tool to two other contrasting livestock production areas, and to a niche system within the Tarn-Aveyron Basin. By doing this, we show the barn could be used to compare services and impacts across livestock production areas, and also for multi-level analysis of services and impacts of livestock farming within a given area. We conclude by discussing the strengths and weaknesses of this graphical tool.

\section{How to represent the diversity of services and impacts of livestock systems?}

When impacts and services of livestock production are analysed and quantified the focus is often on relatively few services or impacts (Tancoigne et al., 2014) and the trade-offs between production and environmental dimensions (De Vries and de Boer, 2010; Scohier and Dumont, 2012; Sabatier et al., 2015). This contrasts with analysing the 'bundle of services' provided by livestock farming (RaudseppHearne et al., 2010). Trade-offs between production and socio-cultural dimensions have been largely overlooked due to methodological challenges (Dolman et al., 2014; Beudou et al., 2017). Cultural services are difficult to quantify because they do not represent purely biophysical phenomena and are given different values by stakeholders. In addition, the emphasis on analysing impacts at field or farm levels has resulted in a lack of information and methods for use at higher scales. Table 1 provides an overview of the primary current methods for assessing the impacts and services of livestock farming, and their limits. Three main limits are discussed in the following sections: (i) a segregation between the evaluation of the negative impacts from agriculture and multi-functionality or ecosystem services frameworks, (ii) an emphasis on agro-environmental impacts over the social aspects and (iii) focussing at the farm level despite recent and promising development of social-ecological approaches at the regional level.

\section{A segregation between the evaluation of the impacts and services}

There has been an emphasis in the scientific literature on the negative environmental impacts of livestock systems (FAO, 2006; Westhoek et al., 2015). The impact of livestock production on the environment has been largely focussed on nutrient and material flow modelling, using either environmental impact assessment tools such as Life Cycle Assessment (LCA), which accounts for all the resources, flows and pollutant emissions associated with the life stages of a product (van der Werf and Petit, 2002; De Vries and de Boer, 2010), or stock and flow analysis (Fernandez-Mena et al., 2016). Conversely, the multi-functionality and ecosystem services frameworks explore a wide range of potential functions and benefits of livestock farming systems, beyond the production of animal proteins. Evaluations of farming systems include carbon storage (Smith, 2014) and flood control by grasslands, landscape aesthetic value, recreation and tourism potential, etc. This approach thus overcomes the 'narrow' focus of the domain- and level-based approaches. Ryschawy et al. (2017a) extended this approach to include territorial vitality (employment in farms, in R\&D and the agrofood industry, stability of employment) and cultural identity (gastronomy, maintenance of hedges, emblematic breeds). However, this type of study is limited in that it does not explicitly account for the negative impacts of livestock production. As an example, when the negative impacts of livestock on water quality was evaluated, low values but not negative values were given for drinking water availability (Turner et al., 2014) or water quality (Ryschawy et al., 2017a). The negative impacts of livestock farming on water quality were thus only accounted for indirectly. However, both the negative environmental impacts and positive ecosystem services need to be simultaneously quantified when 
Ryschawy, Dumont, Therond, Donnars, Hendrickson, Benoit and Duru

Table 1 Main methods developed for assessing the impacts and services of livestock systems ranging from farm to regional and food chain levels

\begin{tabular}{|c|c|c|c|c|}
\hline Methods & Aspects of sustainability covered & $\begin{array}{l}\text { Organizational } \\
\text { level }\end{array}$ & Main limits & References \\
\hline $\begin{array}{l}\text { LCA, nutrient flows, } \\
\text { ecobalances and } \\
\text { footprint } \\
\text { approach }\end{array}$ & $\begin{array}{l}\text { Environment: resources and energy flows, } \\
\text { biogeochemical cycles, water, soil and air } \\
\text { pollutions, greenhouse gas emissions, } \\
\text { wastes (biodiversity under development) } \\
\text { Economic. employment (under development) } \\
\text { Cultural and social: animal health and } \\
\text { welfare }\end{array}$ & $\begin{array}{l}\text { Product, farm, } \\
\text { food chain, } \\
\text { geographical } \\
\text { region }\end{array}$ & $\begin{array}{l}\text { Only quantifies impacts, not services } \\
\text { and does not work with social } \\
\text { impacts } \\
\text { Does not explicitly show the } \\
\text { synergies or trade-offs between } \\
\text { dimensions and scales since the } \\
\text { indicators are aggregated } \\
\text { Sensitivity to functional unit (e.g. per } \\
\text { unit area or per unit product) }\end{array}$ & $\begin{array}{l}\text { van der Werf and Petit } \\
\text { (2002) } \\
\text { De Vries and de Boer } \\
\text { (2010) } \\
\text { Lassaletta et al. (2014) }\end{array}$ \\
\hline $\begin{array}{l}\text { Cost-benefits } \\
\text { approach }\end{array}$ & $\begin{array}{l}\text { Environment: resources and energy flows } \\
\text { Economic. markets and food supply, } \\
\text { employment, policies } \\
\text { Cultural and social: animal health and } \\
\text { welfare }\end{array}$ & $\begin{array}{l}\text { Food-chain, } \\
\text { region }\end{array}$ & $\begin{array}{l}\text { Sensitivity to functional unit (e.g. } \\
\text { performance per unit area or per } \\
\text { unit product) } \\
\text { Limited by data availability in large } \\
\text { national databases }\end{array}$ & $\begin{array}{l}\text { Mc Inerney et al. (1992) } \\
\text { Yrjölä and Kola (2008) }\end{array}$ \\
\hline $\begin{array}{l}\text { Social and cultural } \\
\text { qualitative } \\
\text { analysis }\end{array}$ & $\begin{array}{l}\text { Environment: not taken into account } \\
\text { Economic: markets and food supply, policies, } \\
\text { agro-tourism } \\
\text { Cultural and social: cultural values, rural } \\
\text { vitality }\end{array}$ & Farm, region & $\begin{array}{l}\text { Often not quantified } \\
\text { Time-consuming } \\
\text { Hard to scale-up or transpose to } \\
\text { another context } \\
\text { Highly influenced by the interviewer's } \\
\text { point of view }\end{array}$ & $\begin{array}{l}\text { Lamarque et al. (2011) } \\
\text { Beudou et al. (2017) }\end{array}$ \\
\hline $\begin{array}{l}\text { Social-ecological } \\
\text { approach, } \\
\text { territorial } \\
\text { metabolism }\end{array}$ & $\begin{array}{l}\text { Environment: resources and energy flows, } \\
\text { biodiversity, land-use/landscape structure, } \\
\text { biogeochemical cycles, greenhouse gas } \\
\text { emissions } \\
\text { Economic. markets and food supply, policies } \\
\text { Cultural and social: food safety, rural vitality }\end{array}$ & Region & $\begin{array}{l}\text { Poorly deals with the farm level and } \\
\text { technical approaches } \\
\text { As with most case-study approaches, } \\
\text { it is highly related to the regional } \\
\text { context }\end{array}$ & $\begin{array}{l}\text { Billen et al. (2014) } \\
\text { Bonaudo et al. (2014) } \\
\text { McGinnis and Ostrom } \\
\quad(2014) \\
\text { Sabate et al. (2016) }\end{array}$ \\
\hline $\begin{array}{l}\text { Multi-functionality, } \\
\text { multicriteria and } \\
\text { ecosystem } \\
\text { services } \\
\text { approach }\end{array}$ & $\begin{array}{l}\text { Environment: resources and energy flows, } \\
\text { biodiversity, land-use/landscape structure, } \\
\text { biogeochemical cycles, carbon storage, } \\
\text { greenhouse gas emissions, water, soil and } \\
\text { air pollutions } \\
\text { Economic. markets and food supply, policies } \\
\text { Cultural and social: food safety, rural vitality }\end{array}$ & $\begin{array}{l}\text { Plot, landscape, } \\
\text { region }\end{array}$ & $\begin{array}{l}\text { Poorly deals with farm level and } \\
\text { technical approaches } \\
\text { Difficulty to integrate social aspects, } \\
\text { due to limited data availability in } \\
\text { large databases } \\
\text { Often does not consider negative } \\
\text { impacts explicitly, e.g., in bundle of } \\
\text { services or multi-functionality } \\
\text { approaches }\end{array}$ & $\begin{array}{l}\text { MEA (2005) } \\
\text { Zhang et al. (2007) } \\
\text { Lescourret et al. (2015) } \\
\text { Ryschawy et al. (2017a) }\end{array}$ \\
\hline $\begin{array}{l}\text { Scenario modelling } \\
\text { and mapping }\end{array}$ & $\begin{array}{l}\text { Environment. resources and energy flows, } \\
\text { biological processes, water, soil and air } \\
\text { pollutions, climate change, land-use/ } \\
\text { landscape } \\
\text { Economic. markets and food supply, policies } \\
\text { Cultural and social: food and protein supply, } \\
\text { food security }\end{array}$ & $\begin{array}{l}\text { Farm, region, } \\
\text { country, EU, } \\
\text { world }\end{array}$ & $\begin{array}{l}\text { Lack of available quantitative } \\
\text { indicators in national or global } \\
\text { databases } \\
\text { Models do not capture the social } \\
\text { mechanisms behind transition (e.g. } \\
\text { consumer preferences) } \\
\text { Usually does not include social } \\
\text { aspects } \\
\text { Does not account for the diversity of } \\
\text { livestock production areas }\end{array}$ & $\begin{array}{l}\text { Westhoek et al. (2015) } \\
\text { Chaudhary and Kastner } \\
\quad(2016) \\
\text { Röös et al. (2016) } \\
\text { Dumont et al. (2018b) }\end{array}$ \\
\hline
\end{tabular}

Information is given on the aspects of sustainability and domains covered, level of organization considered and main limits of such methods. Illustration of the methods are provided through selected references.

$\mathrm{LCA}=$ Life Cycle Assessment. 
dealing with the biophysical effects of farming systems on the environment (Barot et al., 2017).

\section{An emphasis on agro-environmental impacts at the detriment of social aspects}

Recent research has focused on developing quantitative agro-environmental indicators (Makowski et al., 2009; Dolman et al., 2014; Zehetmeier et al., 2014) by conducting experiments at plot and farm levels or utilizing national databases. At the same time, economists have concentrated on quantifying market-based flows, especially with costbenefit approaches, and often only consider the economic dimensions and negative aspects of livestock farming (Mc Inerney et al., 1992; Pearce, 2003; Yrjölä and Kola, 2008). This focus on either agro-environmental or economic assessments has resulted in (i) a disconnect between the environmental, economic and social dimensions in the literature (Dumont et al. 2018b), and (ii) multicriteria evaluations of livestock farming that neglect their social dimensions (Oteros-Rozas et al., 2012; Rodríguez-Ortega et al., 2014).

However, recently there have been attempts to develop proxies for social indicators by using information available in databases, such as the number of working hours or the accident of farm workers per year (Röös et al., 2016) or the number of direct and indirect jobs created by the livestock sector (Ryschawy et al., 2017a). Beudou et al. (2017) developed a qualitative approach for evaluating social indicators of livestock systems in two contrasting livestock production areas. Their research revealed that social aspects of livestock production, including the territorial vitality and cultural services can greatly increase local acceptability of livestock farming and may potentially prevent the transition of livestock farming to less industrial systems. Although these works represent progress in better accounting for the social dimensions of livestock farming, they are still limited. There is a lack of indicators and it is difficult to account for shifts in consumer preferences and other social mechanisms that are behind transition to different food systems (Dumont et al., 2018b). The common technique of using interviews is also time-consuming, cannot be easily transposed to other contexts and the outputs cannot be easily quantified.

\section{A focus at farm level in spite of the development of social- ecological approaches}

Evaluation of livestock systems is still focussed at the field/ herd or farm level with less emphasis on the farm environment or multiple stakeholder preferences. Modelling approaches have successfully predicted the environmental impacts of livestock systems at the landscape level by using proxies of landscape heterogeneity that are assumed to benefit biodiversity (Sabatier et al., 2015), but these approaches do not consider any social aspects. More recently, the 'social-ecological system' framework has led to a better understanding of the complexity of the humannature interactions on a range of simultaneously assessed environmental, social and economic dimensions (McGinnis and Ostrom, 2014). While initially developed to deal with natural resource management issues, this approach has been applied to agriculture and food systems, since it could include the physical space dedicated to production (including resources, infrastructure, markets, institutions) and people involved (Cabell and Oelofse, 2012; Lescourret et al., 2015; Vallejo-Rojas et al., 2015). The social-ecological system approaches place the stakeholders in the centre of the agriculture/food system, but they are less effective at considering the biotechnical aspects of farming systems and the interaction with humans and downstream channels (Duru et al., 2015; Marshall, 2015; Touzard et al., 2015). Although highly integrative, these approaches lack the ability to consider product quality, the impact of globalized markets and public policies, and the off-farm impacts embodied in international trade of livestock feed (Chaudhary and Kastner, 2016). Territorial metabolism studies, or more recently the concept of environmental nutrition (Sabate et al., 2016) connect natural processes with the social and technical characteristics of an area (Bonaudo et al., 2014). However, such approaches are rarely used for evaluating livestock production areas.

This short review of existing methodologies for assessing the services and impacts of livestock systems highlights the inadequacy of current approaches in simultaneously accounting for the whole range of economic, environmental and social dimensions of livestock faming. Therefore, we developed an integrated and operational tool that graphically summarizes the ecological and socio-economic aspects of livestock farming by explicitly representing the multiple services and impacts of different systems in a simple yet informative way.

\section{The 'barn': a graphical tool approach to analyse impacts and services provided by livestock farming: application to the Tarn-Aveyron Basin}

\section{Objective and specifications of the tool}

Drawing up a balance sheet with the positive and negative impacts of livestock farming systems is challenging given the weaknesses of existing frameworks to consider the multiplicity of services and impacts of livestock systems, their variability across livestock production areas and farming systems, and the uncertainty of some assessments. We thus developed a graphical tool that can represent the services and impacts provided by livestock systems, and be adapted from the farm to the regional level.

Such a tool would seek to:

- Provide an operational representation of the livestock system as a social-ecological system. In line with Marshall (2015) and Sabate et al. (2016) such a tool should consider the production, processing and consumption of livestock products, public perception of farming and food systems, and explicitly characterize the environmental and socioeconomic context of any livestock farming system.

- Provide the ability to simultaneously consider the environmental, economic and social impacts and services in the same graphic without minimizing any of these categories 
regardless of information or indicator availability. It should integrate quantitative indicators when available but also consider qualitative data and stakeholder knowledge (Bammer, 2005; Beudou et al., 2017).

- Account for all material flows required for and generated by livestock production, and for local and off-farm biophysical impacts on the environment (Billen et al., 2014; Fernandez-Mena et al., 2016). This is important for accounting for supply chains that develop across territories, which need to include off-farm impacts of livestock farming including the production of animal feed (Chaudhary and Kastner, 2016).

\section{Graphical representation of a crop-livestock region}

Within these specifications, we developed a graphical tool that provides an integrated representation of a livestock farming system, seen as a social-ecological system. It is centred around a pentagon which represents the spatial boundaries of the system, either a farm, a livestock farming system or a livestock production area, such as in the example of the Tarn-Aveyron Basin (Ryschawy et al., 2017b), which is a region with a balance between livestock production (mainly ruminants and some poultry) and cash crops (Figure 1; Table 2). Because of its pentagonal appearance, we call our tool the 'barn'. It consists of a multi-level graphical representation that can be used at different scales (farm, farming system or region) defined as county, watershed, farm-network or at the Nomenclature of Territorial Units for Statistics 3 level (NUTS3). Pentagon limits do not need to be linked to a specific administrative area, which allows further flexibility in the representation. Within the pentagon, two shades of green account for permanent and temporary grasslands, and two shades of yellow for the diversity of crop rotations. Natural and agroindustrial infrastructures are the main characteristics of livestock production areas in terms of nature and balance of livestock products and they are represented with intuitive pictograms (Figure 1). Grass-fed animals are in green, those fed concentrate feeds, including maize silage, are in orange. We consider not only interactions within the system (e.g. green circular arrows in Figure 1), but also interactions of the system along five interfaces: (i) Markets, (ii) Work and employment, (iii) Inputs, (iv) Environment and climate, (v) Social and cultural factors. Outward-pointing and inwardfacing arrows around the pentagon allow visualizing the relative importance of variables represented along these five interfaces. The nature of the interaction is given by arrow colours, according to whether these effects are positive (green arrow), negative (red) or mixed (hatched).

\section{The barn represents how the system interacts along five interfaces}

Five interfaces were defined representing how any livestock farming system interacts with its ecological and socioeconomic context. First, we considered two major market types. These are (i) the market for animal products (i.e. provisioning services in Ryschawy et al., 2017a) and (ii) the purchasing of inputs required for production (arable land devoted to soya beans and corn for animal feeds, chemical fertilizers, etc.) that are imported to the system production area (Chaudhary and Kastner, 2016). To do this, we considered that input-based systems are integrated in internationally traded food markets and therefore we needed to consider both their local and global environmental impacts (Marsden, 2011). Among the five interfaces, the three that are the most directly impacted by considering the two different types of markets are as follows:

- Markets. The market interface accounts for the type (pictograms) and quantity of agricultural products, and for opportunities (quality-labelled products represented by the green outward-pointing arrow in Figure 1) and threats (little added-value for young beef represented by red hatches in the outward-pointing arrow, fluctuating prices of crops represented by the red inward-facing arrow) resulting from marketing agreements along the livestock agri-food chains.

- Inputs. While local production of livestock feed (Magne et al., 2016; Table 2) is represented by green circular arrows within the barn, the red inward-facing arrow on the inputs interface represents the quantity of exogenous inputs that are required either directly (fertilizers, veterinary products, etc.) or indirectly (pesticides, nonrenewable energy for concentrate feeds, etc.) for livestock production. Quantification of these indicators is highly dependent on (i) the allocation of land area to different products and by-products, (ii) categories of inputs and (iii) assumptions made to quantify their relative importance (e.g. blue, green and grey water).

- Environment and climate. The interface of the livestock systems with its biophysical environment accounts for the different environmental compartments, that is, different pictograms are used for air, water and soil quality, and biodiversity (Millenium Ecosystem Assessment (MEA), 2005; FAO, 2006). The relative importance of positive and negative impacts of livestock farming on the environment is represented by the size and colour of the outward pointing arrow. In Figure 1, high levels of carbon storage, water quality and biodiversity associated to permanent grasslands are represented by the large green outward-pointing arrow, while high levels of $\mathrm{CH}_{4} / \mathrm{kg}$ of product led to hatching red this arrow. Zhang et al. (2007) and Duru et al. (2015) have also quantified that agricultural production is also the result of biological regulations, soil fertility and erosion control provided by grassland ecosystems to farmers. So-called 'input services' are represented by a green inward-facing arrow in Figure 1. On this interface, we account for the impact of livestock on climate (FAO, 2006) but also for the sensitivity of the livestock systems to climate change (Magne et al., 2016), which can lead to hatching red the input services arrow (Figure $2 \mathrm{~b}$ ).As our graphical tool is explicitly derived from a social-ecological approach, a large emphasis was 

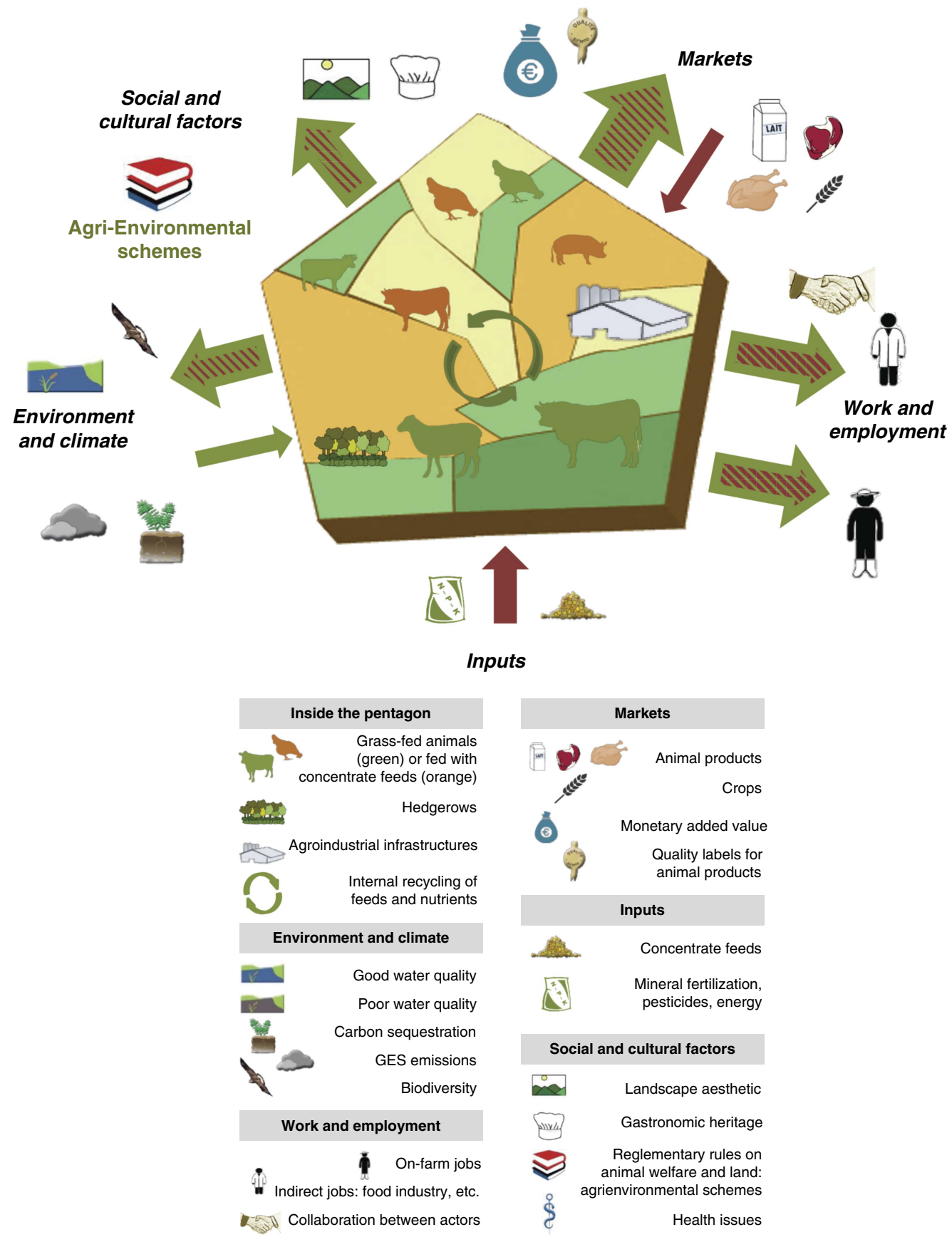

Figure 1 Conceptual framework applied to a crop-livestock region, the Tarn-Aveyron Basin (Moraine et al., 2016; Ryschawy et al., 2017b). The pentagon is spatially representing the livestock system considered. The diversity and proportion of land use is represented with two shades of green for permanent and temporary grasslands, and two shades of yellow to account for the diversity of crop rotations. Natural infrastructures (hedges, forests, etc.) and the agro-industrial buildings related to livestock production are also graphically represented. Balances between livestock production are symbolized by size of animal species pictograms (dairy and beef cattle, pigs, poultry, sheep). Grass-fed animals are green and livestock fed concentrates including maize silage and protein-rich feed cakes are represented by orange. Orange animals are more likely to be confined which is typical for intensive pig and poultry systems. The magnitude of impacts or services are represented by the size of outward-pointing arrows, and by their colour. Input services benefiting grassland-based systems are represented by a green inward-facing arrow on the Environment and climate interface. More globally arrow colours indicate positive (green), negative (red) or mixed (hatched with the dominant effect indicated by the colour of the outside border) effects.

placed on the role of stakeholders. Following Marshall (2015), we separated stakeholders involved in the livestock sector into either on-farm or from indirect jobs, or citizens and consumers whose values and ethical considerations are accounted for on the social and cultural interface.
- Work and employment. This interface focuses on on-farm and indirect jobs (represented by two distinct pictograms), working conditions (modulating arrow colour) and organization of supply chains with a specific pictogram accounting for collaboration between actors. How livestock contributes to local employment, employee status 
Ryschawy, Dumont, Therond, Donnars, Hendrickson, Benoit and Duru

Table 2 Table providing a synthesis of the services and impacts in a crop-livestock region: the Tarn-Aveyron Basin case-study

\begin{tabular}{|c|c|c|}
\hline Interfaces & Positive effects - services & Negative effects - impacts \\
\hline Inputs & $\begin{array}{l}\text { Local production of livestock feed (Magne et al., 2016) } \\
\text { is represented by green circular arrows within the } \\
\text { barn }\end{array}$ & $\begin{array}{l}\text { Off-farm impacts linked to soya bean imports (Magne et al., } \\
\text { 2016) } \\
\text { Mineral fertilization of crops; water used for maize (Murgue } \\
\text { et al., 2015) }\end{array}$ \\
\hline Labour and employment & $\begin{array}{l}\text { Direct employment of farmers in many little farms } \\
\text { (Ryschawy et al., 2017a) } \\
\text { Indirect employment in local transformation of livestock } \\
\text { products, cooperatives, etc. (Ryschawy et al., 2017a) }\end{array}$ & Low remuneration of work in farms and local supply chains \\
\hline Markets & $\begin{array}{l}\text { Lots of quality-labelled products and direct sale (Beudou } \\
\text { et al., 2017) }\end{array}$ & $\begin{array}{l}\text { Little added-value for young beef (Moraine et al., 2016) } \\
\text { Fluctuating prices of crops on global market (Ryschawy et al., } \\
\text { 2019) }\end{array}$ \\
\hline Social and cultural factors & $\begin{array}{l}\text { High nutritional quality of grass-fed ruminant products } \\
\text { (Duru et al., 2017) } \\
\text { Aesthetic of mosaic landscapes and gastronomy } \\
\text { heritage (Beudou et al., 2017) }\end{array}$ & $\begin{array}{l}\text { Conflict on the use of water, largely due to the high quantities } \\
\text { required for maize silage (Murgue et al., 2015) }\end{array}$ \\
\hline Environment and climate & $\begin{array}{l}\text { High level of biodiversity in permanent grasslands and } \\
\text { agroecological infrastructures (Moraine et al., 2016) } \\
\text { Carbon storage in grasslands } \\
\text { Water quality preservation }\end{array}$ & $\begin{array}{l}\text { High level of } \mathrm{CH}_{4} / \mathrm{kg} \text { of product (Duru et al., 2017) } \\
\text { Sensivity of grassland systems to climate, and of crops to pests } \\
\text { (Magne et al., 2016) }\end{array}$ \\
\hline
\end{tabular}

(including stability of employment) and working conditions varies across livestock sectors (Hostiou and Fagon, 2012; Röös et al., 2016). Employment is a major opportunity in high animal densities regions and in some rural areas where livestock farming creates a lot of jobs. Livestock management practices are also challenging, particularly in considering how farm labour is organized (Hostiou and Dedieu, 2012). Technology and automation do have a direct impact on number of working hours, but their social effects are controversial (Dumont et al., 2018a).

- Social and cultural factors. This interface incorporates a range of topics such as cultural heritage, ethical considerations (e.g. on animal welfare) and reglementary rules relative to land use (e.g. agri-environmental schemes). The relationships between animal health, consumption of animal products and human health are embodied in the one-health framework (Sabate et al., 2016). In the global North, animal welfare is a major social concern, resulting in controversies revolving around industrial livestock systems (Delanoue et al., 2018). Livestock systems also contribute to creating readily identifiable cultural landscapes and often support local gastronomy. Social and cultural factors cannot yet be quantified at a large scale using available databases, but some attempts have been initiated locally using qualitative approaches (Beudou et al., 2017). Our framework provides for this important interface to be evaluated along the lines of some recent attempts for a more global evaluation of livestock farming systems or landscapes (Plieninger et al., 2013; Röös et al., 2016).

Coloured arrows represent the impacts and services provided by livestock farming

Thanks to arrow size, the 'barn' allows end-users to visualize the relative importance of variables represented along the five interfaces. It should be noted that arrow size can either account for monetary data from traded volumes (on Markets and Inputs interfaces), number of workers (Work and employment) or for the magnitude of effects (Environment and climate; Social and cultural factors). Outward-pointing arrows have up to three different sizes reflecting the magnitude of the effect. A thin, intermediate and large arrow corresponds to a low, intermediate and large impact/service, respectively. The nature of the interaction is given by arrow colours. Using hatched arrows provide our graphical representation with more flexibility. For instance, there could be a high number of jobs in the livestock agro-food industry (represented by a large green arrow) but low wages in the sector, which leads to hatching this arrow red (see other trade-offs in previous Markets and Environment and climate sub-sections). Inward-facing arrows represent either opportunities (direct sales on Markets interface or input services on Environment and climate interface) or external pressures (fluctuating prices on the global market, dependence to external inputs and predation risks, on the Markets, Inputs and Environment and climate interfaces, respectively) that affect livestock production systems. Inward facing arrows can also have three different sizes.

\section{How to analyse and process information to produce the graphical outcome?}

When developing the 'barn', we used a combination of quantitative and qualitative indicators but focus on quantitative indicators when available. The Markets and Inputs interfaces could be evaluated through monetary data, which is available through large databases such as Farming Accountancy Data Network or through farmers' interviews for barns produced at a finer level. The Work and employment interface can utilize data on the number of workers in 
(a)

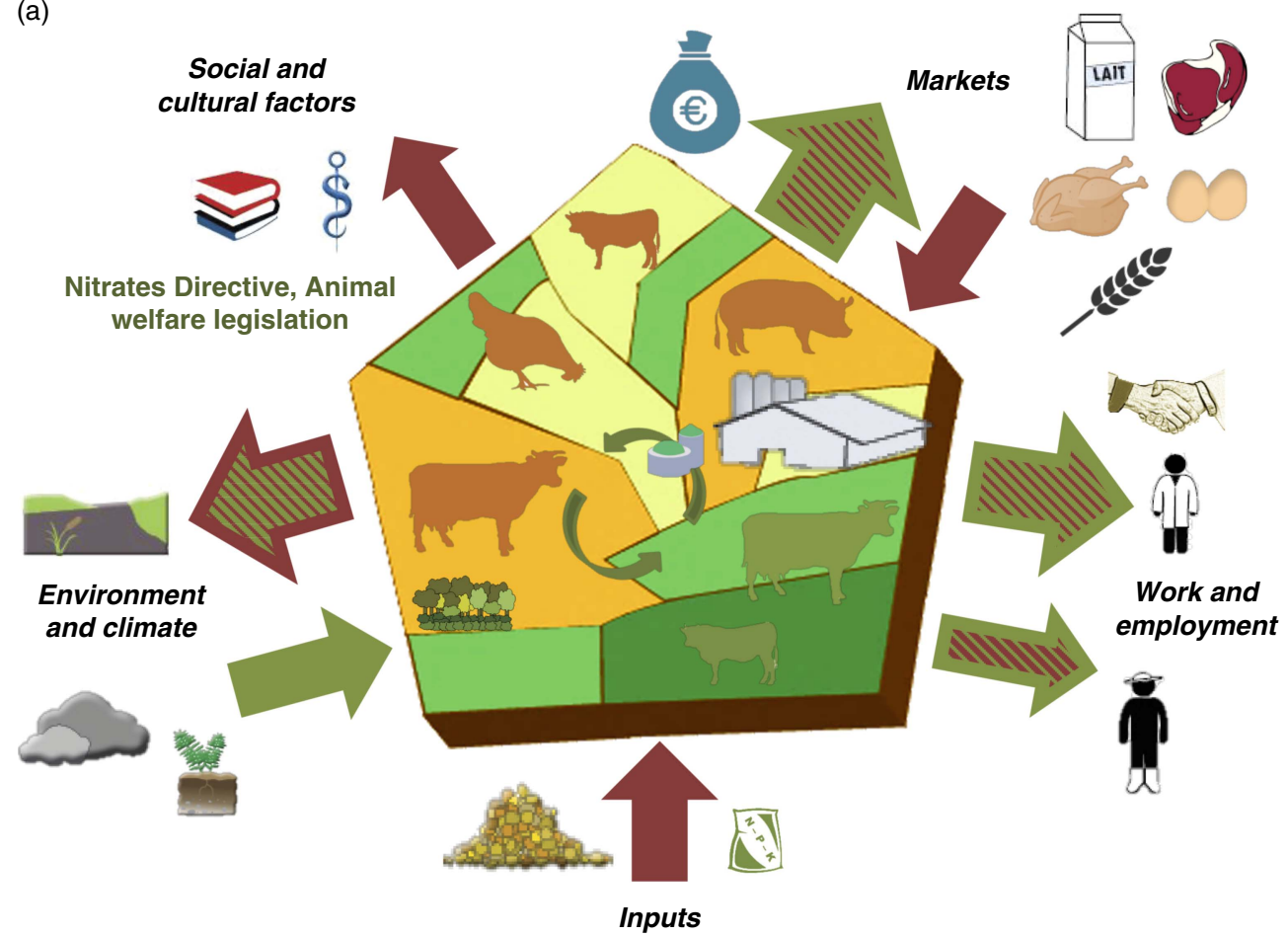

(b)

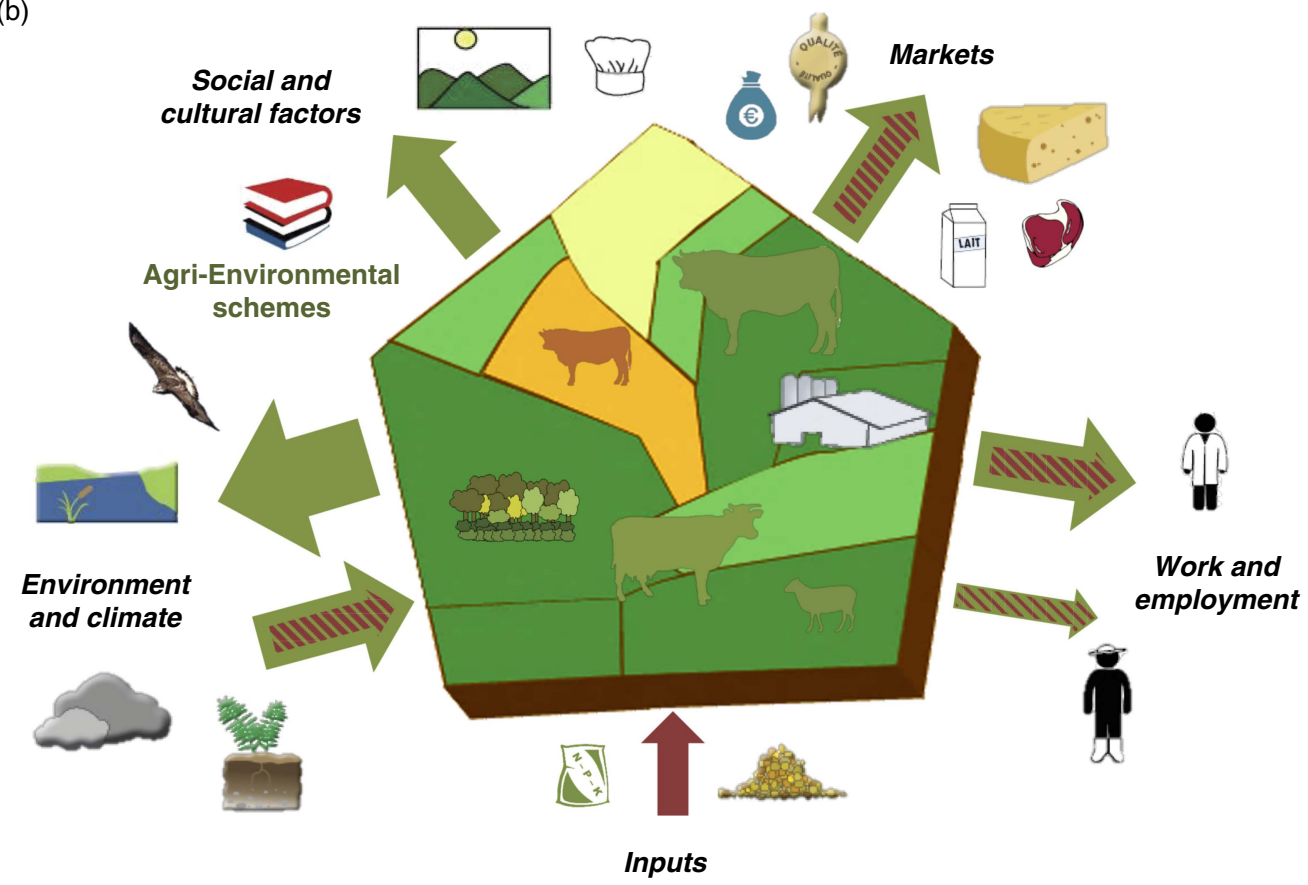

Figure 2 Contrasting examples of trade-offs and synergies between the sides of the 'barn'. Brittany (a) is an example of high livestock density regions with a trade-off between high production levels and environmental and cultural impacts (Dourmad et al., 2017). Massif central (b) is an example of grassland-based regions with lower production levels but more synergies with environmental and cultural services (Duru et al., 2017; Vollet et al., 2017). See Figure 1 for pictogram meaning.

the livestock sector in France from the National Institute for Statistics and Economic studies and from the Agricultural Mutual Assistance Association at NUTS3 level; however, statistical confidentiality may apply at finer level (Ryschawy et al., 2017a). Values for the Environment and climate interface were standardized between 0 and 1 by Ryschawy et al. (2017a). They can then be compared and identified as services or impacts depending on whether the value was higher or below a threshold value of 0.5 . For instance, the proportion of counties outside nitrate vulnerable zones (i.e. below the legal threshold of $50 \mathrm{mg} /$; Dourmad et al., 2017) was used as a water quality indicator. It was considered to be negative when it was below 0.5 and led to a red arrow and a grey water-quality pictogram in Catalonia (Dumont et al., 
2018b) and Brittany (Dourmad et al., 2017; Figure 2). However, when it was greater than 0.5 , it was considered as a service and this information was used to develop the green arrow and a blue water-quality pictogram in Franche Comté and Provence (Vollet et al., 2017; Dumont et al., 2018b). Synthesizing the information on the different environmental compartments into a single outward-pointing arrow was expert-based since there were no common metrics for air, water and soil quality, and biodiversity (Figure 1). This approach was considered valid because experts from various domains and knowing the different livestock production areas were consulted. In addition, the environmental criteria was understood and well accepted, and the number of criteria was small enough to be considered as a group by the experts (Bouyssou, 1990). A literature search revealed very few quantitative indicators for the Social and cultural factors interface (Plieninger et al., 2013, Beudou et al., 2017). Therefore, this interface was analysed using expert knowledge or through knowledge exchange with local stakeholders or policy-makers as suggested by Bammer (2005).

The 'barn' aims to explicitly reveal the synergies and tradeoffs between services and impacts. Using a number of distinct pictograms allows data to be interpreted on one interface, and limits the loss of information which can occur through aggregation. As Ryschawy et al. (2017a) suggested, no weighing is suggested a priori but local stakeholders could prioritize some interfaces according to their viewpoints on livestock systems. The absence of a pictogram or of an arrow may not mean that the factor was absent, but rather that it was considered negligible compared with other livestock production areas or farming systems. Pictograms are not limited in number, since new pictograms could be added if needed for other livestock production areas (Dernat et al., 2019).

\section{Application of the barn to other contexts}

In the previous section, we analysed processing information to produce the graphical representation of the Tarn-Aveyron Basin. In this section, we will use the barn to compare (i) two contrasting livestock production areas (high livestock density $v$. grassland-based), and (ii) the dominant $v$. a niche system within the Tarn-Aveyron Basin.

\section{Comparing a high livestock density v. a grassland-based production area}

One of the strengths of the 'barn' is the ability to compare livestock production areas by standardizing the indicators through three possible arrow sizes and different types, sizes and colours of pictograms. Figure 2 shows a crosscomparison of the synergies and trade-offs between services and impacts in two contrasting French regions, Brittany and Massif central. Brittany (Dourmad et al. 2017) is an example of an area with high livestock densities that has trade-offs between high production and employment on one side and high local environmental impacts on the other that can lead to an overall negative image of livestock production systems by society. In comparison, in the French Massif central, located mainly in the Auvergne region, Protected Designation of Origin (PDO) production (Duru et al., 2017; Vollet et al., 2017), contributes to grassland-based landscapes with moderate livestock density, improved synergies between production, environmental and cultural services, and a better societal acceptability of livestock production.

The comparison in Figure 2 illustrates how the 'barns' can rely on numerical values for services and impacts. The size of the pictograms and arrows match technical and socioeconomic references from DGAGRI - RICA EU 2015 (Hercule et al. 2017). In 2015, Brittany had a total of 20.080 livestock farms (46\% dairy cattle, $27 \%$ pigs and poultry, $9 \%$ beef cattle) and Auvergne had 12.100 livestock farms ( $46 \%$ beef cattle, 34\% dairy cattle, $8 \%$ small ruminants), which corresponds to the animal pictogram size in the two barns (Figure 2). Regional differences in on-farm job numbers (40.360 v. 25.290 in Brittany and Auvergne, respectively) and in agricultural production (129.900 v. 68.300 euros per farm worker) are also consistent with contrasting arrow size on the Work and employment, and Markets interfaces. Ruminant production in Auvergne relies more on subsidies than in Brittany (Hercule et al., 2017), and so agrienvironmental schemes were indicated on the Social and cultural factors interface of the Massif central barn. Conversely, in high livestock density areas, policies such as the EU Nitrates Directive aim to regulate the local water and air pollution from intensive farming, and are mentioned on the Social and cultural factors interface. Finally, using LCA, it would be possible to quantify off-farm impacts due to feed imports while other variables (biodiversity, water quality, etc.) can be quantified by using longitudinal surveys or networks to determine the size of pictograms and arrows on the Environment and climate and Inputs interfaces.

Comparing alternative farming systems in the same region The 'barn' concept could be applied in a same region but at different organizational scales (county, collective of farms, etc.). Doing this may reveal production market-niches, which are often hidden by the dominant socio-technical regime. In the Tarn-Aveyron Basin, local stakeholders have highlighted the reputation and diversity of quality-labelled products associated with various ruminant farming systems, and also with monogastric farms using local maize (geese and fattened ducks) (Moraine et al., 2016). The coexistence of these systems provides significant benefits for the landscape and local gastronomy and gives tourists a high environmental quality experience. However, the degree of integration between crop and livestock farms may be variable and limited, and there are conflicts over water use because of the high quantities of water required to produce maize silage (Murgue et al., 2015).

Applying the multi-level perspectives framework of Schot and Geels (2007) to this crop-livestock region, it could be considered that systems with low level of technical integration between crops and livestock are the dominant socio- 
technical regime for crop-livestock farming (Figure 1), while highly integrated crop-livestock system maximizing interactions between animals, crops and grasslands are a market niche system. In Figure 3, the 'barn' framework was applied to this type of market-niche system within the Tarn-Aveyron Basin. The 'barn' in this example, was developed using knowledge exchange between farmers, their adviser and researchers as a tool (Bammer, 2005). The market-niche is comprised of seven specialized farms (three crop farms and four livestock farms) on a study area of 201 ha (Ryschawy et al., 2019). The producers on these farms are developing resource exchanges between neighbours to become self-sufficient in fertilizer and animal-feed inputs. Currently, livestock farmers are not totally self-sufficient in producing animal feed; they need to buy four tons of sunflower and 18 tons of maize produced by crop farmers within the collective. In addition, the collective's self-sufficiency in livestock feed and soil conditions were enhanced since crop farmers produce 44 tons of barley-pea mixtures and 8 tons of alfalfa in their rotations. Livestock farmers provide 100 tons of manure per year to crop farmers which help limit their mineral fertilizer inputs. The size of green circular arrows within the barn was increased to represent nutrient cycling through feed crops and manure exchanges within the collective, while the red inward-facing arrow on the Inputs interface was reduced.

There were still logistical and social issues because of the increased workload and the need for a different set of management skills. However, the trade-offs between individual and collective benefits were acceptable and resulted in better working conditions and greater self-sufficiency in decision-making at the collective level (Moraine et al., 2016). The group in the study was organic and direct markets its products. The collective's Market interface was thus clearly improved (Figure 3) compared to the common practice of selling young live cattle to the Italian market, where returns are poorer since the animals are not fattened (Figure 1). There were fewer people employed in the supply-chain sector (Figure 3) because the farmers in the collective focus on reducing off-farm inputs resulting in lower employment in input-suppliers and commercialization firms. Finally, the Social and cultural factors interface benefited from reduced water use linked to the reduced production of maize silage, and from the positive image provided by quality-labelled products in a preserved landscape mosaic.

\section{Strengths and weaknesses of the 'barn'}

The main strength of the 'barn' is the possibility to integrate multi-disciplinary knowledge, especially with stakeholders, and therefore account for generic and local knowledge. Multicriteria analysis and methods examining 'bundles of services' highlight the synergies and trade-offs between services but most assessments aggregate indicators (Table 1), which suggests that negative effects on one dimension could be counterbalanced by an improvement on another. This, however, requires caution due to the complex nature of these interactions, and because different stakeholders can develop their own system of value for the impacts and services provided by livestock farming (OterosRozas et al., 2012; Clark et al., 2017). Reaching high performance in all dimensions of sustainability is difficult to achieve, as shown by the frequent trade-off between livestock production on one side and most regulating and cultural services on the other (Turner et al., 2014; Dumont et al., 2018b). A primary innovation of the 'barn' is that it explicitly represents all the impacts of livestock farming. For example, we utilized a red arrow and a grey water pictogram to explicitly visualize water pollution in Brittany and Catalonia (Dourmad et al., 2017; Dumont et al., 2018b) in contrast to the bundle of services method that accounts only for services (Turner et al., 2014; Ryschawy et al., 2017a). Therefore, no hidden cost or benefit of livestock farming is excluded from the graphical representation, and local knowhow can be used to fill gaps in scientific knowledge when no validated indicators are available (Dolman et al., 2014). Winwin solutions are more likely to emerge when they result from collective decisions that include the point of view of various stakeholders (Howe et al., 2014). This highlights the importance of accounting for the whole socio-ecological system as was done with the 'barn'.

The 'barn' graphically summarizes the ecological and socio-economic aspects of livestock farming. It has already been used as a pedagogical approach with advanced students to compare the synergies and trade-offs between impacts and services across a range of European livestock production areas facing highly contrasted pedoclimatic and livestock density conditions. This appeared as a powerful tool that made them realize there is no perfect situation since all livestock regions have advantages and limitations, but in some case studies more balanced bundles of services were provided (Ryschawy et al., 2017b; Vollet et al., 2017; Dumont et al., 2018b; Figure 3). Such a graphical tool could be easily adapted to other agricultural systems, while adding some pictograms and using the same way of quantifying the indicators based on available quantitative indicators and/or expertknowledge. So far, a total 24 barns have been built from case studies in France, Ireland, Spain, Switzerland and Germany but the tool has not been tested yet outside Europe. It is noteworthy that analysing and processing information to quantify arrow and pictogram sizes more easily applies when comparable data are available for the different livestock production areas or systems being compared.

The 'barn' is a structured graphical tool that can help a large diversity of stakeholders (farmers, individuals involved in supply chains, policy-makers, Non-governmental organizations, etc.) understand key opportunities and threats related to livestock production, and quickly identify relationships between the main features of a system at a given scale. As proposed by Bammer (2005), such a framework could be a way of implementing science through knowledge exchange with local stakeholders. Any stakeholder can stress the relevant challenges for local livestock farming and share his views on any of the synergies, trade-offs, co-ordinations or scenarios that are visualized using the 'barn'. Decisions and prioritization between 


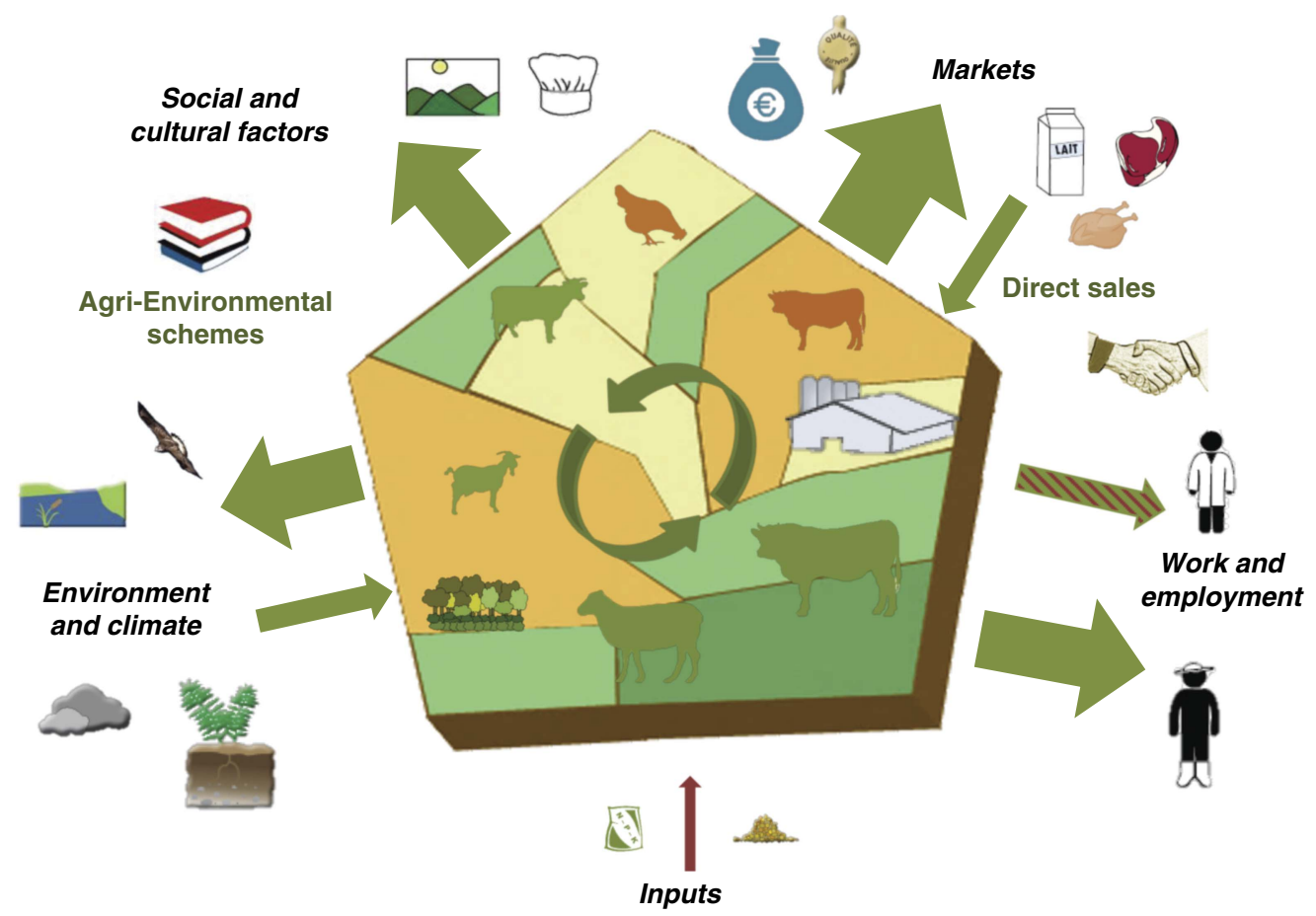

Figure 3 Application of the 'barn' framework to a niche-system in the Tarn-Aveyron Basin. It is composed of a collective of seven organic farmers that are developing resource exchanges between neighbours to become self-sufficient in fertilizer and animal-feed inputs (Ryschawy et al., 2019). The internal exchanges helps reduce external inputs, increase soil carbon storage and resulted in a more balanced bundle of services with more green arrows on the different interfaces. See Figure 1 for pictogram meaning.

scenarios can then be discussed based on expert opinion, as shown by Lamarque et al. (2011) for Alpine grassland-based landscapes and Moraine et al. (2016) for a crop-livestock region. In the Fourme de Montbrison PDO area, the 'barn' was used for the first time as serious-game in October 2018 on a large stakeholder panel $(n=98)$ from this territory (Dernat et al., 2019). It facilitated the PDO actors' recognition of their natural, technical, economic and institutional environment. It also helped establish a collaboration between stakeholders that provides for their individual representations and leads to a more global and unified view of their territory (Dernat et al., 2019). The objective of building alternative scenarios for the future of this PDO production area was achieved and this exercise proves the operationality of the 'barn'.

As with any visual representation, the heuristic scope of the 'barn', however, remains limited as not all interactions can be described. The 'barn' focusses on interactions related to livestock systems. We have chosen a spatial structure, with reference to land use that can be either a farm, a farming system or a production area. Skills and interknowledge networks cannot be simply visualized using such a diagram, even though they contribute to system dynamics (Dumont et al., 2018a). Not all interlocking territories can also be represented in a single diagram, but it is noteworthy that exported impacts embodied in international food trade are explicitly represented on the Inputs interface, while other global impacts are accounted for on Markets and Environment and climate interfaces. Our approach could be extended to or complementary to food systems framework as suggested by Sabate et al. (2016), in which the focus is more on consumers and health issues.
The 'barn' has been presented here as a static representation of livestock production areas. Irreversibilities and non-linearities also are not explicitly represented but this is also true in all current types of graphical representation. Still, the 'barn' can be used to represent the trajectory of change of any livestock farming system by considering the system representation at current time and either its historical perspective or projected representation in the future according to various evolutionary scenarios. Trajectories of French livestock regions have been studied by Domingues et al. (2018) based on national databases from 1938 to 2010. This type of data could thus be used to develop a temporal analysis of the trajectories of change of French livestock regions and the underlying drivers. When using the barn in the Fourme de Montbrison PDO area, two evolutionary scenarios were represented. They were, a 'business as usual' scenario and an 'enforced territorial organization' scenario which aimed to create more value by better organizing the local transformation chain and enhancing the local resource use (Vollet et al., 2017). The 'barn' could be a first step to identify the opportunities and threats to the future of livestock production from the farm up to the regional level. Its operationality can help identify transition pathways for improving livestock sustainability in the future as recommended by Pigford et al. (2018).

\section{Acknowledgements}

This work is part of the collective scientific assessment (ESCo) of the 'Role, impacts and services provided by European livestock 
production' that was carried out by INRA at the request of the French ministries responsible for Agriculture and the Environment, in cooperation with the French Environment and Energy Management Agency (ADEME). The authors are grateful to Jean-Yves Dourmard, Dominique Vollet, Isabelle Veissier and other experts from ESCo panel, and to Sylvain Dernat for fruitful discussions.

\section{Declaration of interest}

The authors declare no competing interests regarding this publication.

\section{Ethics statement}

Section is irrelevant for this publication.

\section{Software and data repository resources}

No new software or database were generated at part of the outcomes of this work.

\section{References}

Aguilar J, Gramig GG, Hendrickson JR, Archer DW, Forcella F and Liebig MA 2015. Crop species diversity changes in the United States. PLoS One 10, 1978-2012.

Bammer G 2005. Integration and implementation sciences: building a new specialization. Ecology and Society 10,6.

Barot S, Yé L, Abbadiea L, Blouinc M and Frascaria N 2017. Ecosystem services must tackle anthropized ecosystems and ecological engineering. Ecological Engineering 99, 486-495.

Beudou J, Martin G and Ryschawy J 2017. Cultural and territorial vitality services play a key role in livestock agroecological transition in France. Agronomy for Sustainable Development 37, 36.

Billen G, Lassaletta L and Garnier J 2014. A biogeochemical view of the global agro-food system: nitrogen flows associated with protein production, consumption and trade. Global Food Security 3, 209-219.

Bonaudo T, Billen G, Garnier J, Barataud F, Bognon S, Marty P and Dupré D 2014. La transition du système agro-alimentaire d'Aussois au XXe siècle: un cas d'étude du découplage progressif de la production et de la consommation alimentaire. In Conférence Interdisciplinaire sur I'Ecologie Industrielle et Territoriale, 9-10 Octobre 2014, Troyes, France, pp. 1-9.

Bouyssou D 1990. Building criteria: a prerequisite for MCDA. In Readings in multiple criteria decision-aid (ed. CA Bana e Costa), pp. 58-80. Springer Verlag, Heidelberg, Germany.

Cabell JF and Oelofse M 2012. An indicator framework for assessing agroecosystem resilience. Ecology and Society 17, 18.

Chaudhary A and Kastner T 2016. Land use biodiversity impacts embodied in international food trade. Global Environmental Change 38, 195-204.

Clark B, Stewart GB, Panzone LA, Kyriazakis I and Frewer LJ 2017. Citizens, consumers and farm animal welfare: a meta-analysis of willingness-to-pay studies. Food Policy 68, 112-127.

De Vries M and de Boer IJM 2010. Comparing environmental impacts for livestock products: a review of life cycle assessments. Livestock Science 128, 1-11.

Delanoue E, Dockes AC, Choteau A, Roguet C and Philibert A 2018. Regards croisés entre éleveurs et citoyens français: vision des citoyens sur l'élevage et point de vue des éleveurs sur leur perception par la société. INRA Productions Animales 31, 51-68.

Dernat S, Vollet D, Cayre P and Dumont B 2019. Accompanying the collective construction of a plan for the future. The case of a collaborative and territorialized process for the actors of the PDO cheese 'Fourme de Montbrison' (Loire, France). In Agricultural Education and Extension Tuned on Innovation for Sustainability. Experiences and perspectives, Proceedings of the $24^{\text {th }}$ European Seminar on Extension and Education, 18-21 June 2019, Acireale, Italy, pp. 1-2.

Dolman MA, Sonneveld MPW, Mollenhorst $\mathrm{H}$ and de Boer IJM 2014. Benchmarking the economic, environmental and societal performance of Dutch dairy farms aiming at internal recycling of nutrients. Journal of Cleaner Production 73, $45-252$.

Domingues JP, Ryschawy J, Bonaudo T, Gabrielle B and Tichit M 2018. Unravelling the physical, technological and economic factors driving the intensification trajectories of livestock systems. Animal 12, 1652-1661.

Dourmad JY, Delaby L, Boixadera JL, Ortis C, Méda B, Gaigné C and Dumont B 2017. Diversité des services rendus par les territoires à forte densité d'élevages, trois cas d'études en Europe. INRA Productions Animales 30, 303-320.

Dumont B, Groot JCJ and Tichit M 2018a. Review: Make ruminants green again - how can sustainable intensification and agroecology converge for a better future? Animal 12, s210-s219.

Dumont B, Ryschawy J, Duru M, Benoit M, Chatellier V, Delaby L, Donnars C, Dupraz P, Lemauviel-Lavenant S, Méda B, Vollet D and Sabatier R 2018b. Review: Associations among goods, impacts and ecosystem services provided by livestock farming. Animal, first published online 18 October 2018, https://doi. org/10.1017/S1751731118002586.

Duru M, Donnars C, Ryschawy J, Therond O and Dumont B 2017. La " grange » : un cadre conceptuel pour appréhender les bouquets de services rendus par I'élevage dans les territoires. INRA Productions Animales 30, 273-284.

Duru M, Therond O, Martin G, Martin-Clouaire R, Magne MA, Justes E and Sarthou JP 2015. How to implement biodiversity-based agriculture to enhance ecosystem services: a review. Agronomy for Sustainable Development 35, 1259-1281.

Fernandez-Mena H, Nesme T and Pellerin S 2016. Towards an agro-industrial ecology: a review of nutrient flow modelling and assessment tools in agro-food systems at the local scale. Science of the Total Environment 543, 467-479.

Food and Agricultural Organization (FAO) 2006. Livestock's long shadow. Environmental issues and options. FAO, Rome, Italy.

Hercule J, Chatellier V, Piet L, Dumont B, Benoit M, Delaby L, Donnars C, Savini I and Dupraz P 2017. Une typologie pour représenter la diversité des territoires d'élevage en Europe. INRA Productions Animales 30, 285-302.

Hostiou N and Dedieu B 2012. A method for assessing work productivity and flexibility in livestock farms. Animal 6, 852-862.

Hostiou N and Fagon J 2012. Simplification des conduites d'élevage: analyse transversale des pratiques mises en oeuvre dans les filières herbivores et granivores. INRA Productions Animales 25, 127-140.

Howe C, Suich H, Vira B and Mace GM 2014. Creating win-win from trade-offs? Ecosystem services for human well-being: a meta-analysis of ecosystem services trade-offs and synergies in the real world. Global Environmental Change 28, 263-275.

Lamarque $\mathrm{P}$, Tappeiner U, Turner C, Steinbacher M, Bardgett RD, Szukics U, Schermer M and Lavorel S 2011. Stakeholder perceptions of grassland ecosystem services in relation to knowledge on soil fertility and biodiversity. Regional Environmental Change 11, 791-804.

Lassaletta L, Billen G, Grizzetti B, Garnier J, Leach AM and Galloway JN 2014. Food and feed trade as a driver in the global nitrogen cycle: 50 -year trends. Biogeochemistry 118, 225-241.

Lemaire G, Gastal F, Franzluebbers A and Chabbi A 2015. Grassland-cropping rotations: an avenue for agricultural diversification to reconcile high production with environmental quality. Environmental Management 56, 1065-1077.

Lescouret F, Magda D, Richard G, Adam-Blondon AF, Bardy M, Baudry J, Doussan I, Dumont B, Lefèvre F, Litrico I, Martin-Clouaire R, Montuelle B, Pellerin $S$, Plantegenest $M$, Tancoigne $E$, Thomas A, Guyomard $H$ and Soussana JF 2015. A social-ecological approach to managing multiple agro-ecosystem services. Current Opinion in Environmental Sustainability 14, 68-75.

Magne MA, Thenard V and Mihout S 2016. Initial insights on the performances and management of dairy cattle herds combining two breeds with contrasting features. Animal 10, 892-901.

Makowski D, Tichit M, Guichard L and Van Keulen H 2009. Measuring the accuracy of agro-environmental indicators. Journal of Environmental Management 90, 139-146. 


\section{Ryschawy, Dumont, Therond, Donnars, Hendrickson, Benoit and Duru}

Marsden T 2011. From post-productionism to reflexive governance: contested transitions in securing more sustainable food futures. Journal of Rural Studies 29, 123-134.

Marshall GR 2015. A social-ecological systems framework for food systems research : accommodating transformation systems and their products. International Journal of the Commons 9, 1-28.

McGinnis MD and Östrom E 2014. Social-ecological system framework: initial changes and continuing challenges. Ecology and Society 19, 30.

Mc Inerney JP, Howe KS and Schepers JA 1992. A framework for the economic analysis of disease in farm livestock. Preventive Veterinary Medicine 13, 137-154. Millenium Ecosystem Assessment (MEA) 2005. Ecosystems and human wellbeing: synthesis. World Resources Institute, Washington, DC, USA.

Moraine M, Grimaldi J, Murgue C, Duru M and Therond 0 2016. Co-design and assessment of cropping systems for developing crop-livestock integration at the territory level. Agricultural Systems 147, 87-97.

Murgue C, Therond 0 and Leenhardt D 2015. Towards sustainable water and agricultural land management: participatory design of spatial distributions of cropping systems in a water-deficit basin. Land Use Policy 45, 52-63.

Oteros-Rozas E, Gonzalez JA, Martin-Lopez B, Lopez CA, Zorrilla-Miras P and Montes C 2012. Evaluating ecosystem services in transhumance cultural landscapes an interdisciplinary and participatory framework. Gaia-Ecological Perspectives for Science and Society 21, 185-193.

Pearce D 2003. Conceptual framework for analysing the distributive impacts of environmental policies. In OECD Environment Directorate Workshop on the Distribution of Benefits and Costs of Environmental Policies, Paris, France.

Pigford AAE, Hickey GM and Klerkx L 2018. Beyond agricultural innovation systems? Exploring an agricultural innovation ecosystems approach for niche design and development in sustainability transitions. Agricultural Systems 164, 116-121.

Plieninger T, Dijks S, Oteros-Rozas E and Bieling C 2013. Assessing, mapping, and quantifying cultural ecosystem services at community level. Land Use Policy 33, 118-129.

Raudsepp-Hearne C, Peterson GD and Bennett EM 2010. Ecosystem service bundles for analyzing tradeoffs in diverse landscapes. Proceedings of the National Academy of Sciences 107, 5242-5247.

Rodríguez-Ortega T, Oteros-Rozas E, Ripoll-Bosch R, Tichit M, Martín-López B and Bernués A 2014. Applying the ecosystem services framework to pasturebased livestock farming systems in Europe. Animal 8, 1361-1372.

Röös E, Patel M, Spångberg J, Carlsson G and Rydhmer L 2016. Limiting livestock production to pasture and by-products in a search for sustainable diets. Food Policy 58, 1-13.

Ryschawy J, Benoit M, Hostiou N and Delfosse C 2017b. Quelles concurrences et synergies entre cultures et élevage dans les territoires de polyculture-élevage ? INRA Productions Animales 30, 363-380.

Ryschawy J, Disenhaus C, Bertrand S, Allaire G, Aznar O, Plantureux S, Josien E, Guinot C, Lasseur J, Perrot C, Tchakerian E, Aubert C and Tichit M 2017a. Assessing multiple goods and services derived from livestock farming on a nation-wide gradient. Animal 11, 1861-1872.
Ryschawy J, Moraine M, Péquignot $M$ and Martin G 2019. Trade-offs among individual and collective performances related to crop-livestock integration among farms: a case study in southwestern France. Organic Agriculture, first published online 7 December 2018, https://doi.org/10.1007/s13165-0180237-7.

Sabate J, Harwatt $\mathrm{H}$ and Soret S 2016. Environmental nutrition: a new frontier for public health. American Journal of Public Health 106, 815-821.

Sabatier R, Teillard F, Rossing WAH, Doyen L and Tichit M 2015. Trade-offs between pasture production and farmland bird conservation: exploration of options using a dynamic farm model. Animal 9, 899-907.

Schot J and Geels FW 2007. Niches in evolutionary theories of technical change. Journal of Evolutionary Economics 17, 605-622.

Scohier A and Dumont B 2012. How do sheep affect plant communities and arthropod populations in temperate grasslands? Animal 6, 1129-1138.

Smith P 2014. Do grasslands act as a perpetual sink for carbon? Global Change Biology 20, 2708-2711.

Tancoigne E, Barbier M, Cointet JP and Richard G 2014. The place of agricultural sciences in the literature on ecosystem services. Ecosystem Services 10, 35-48.

Touzard JM, Temple L, Faure G and Triomphe B 2015. Innovation systems and knowledge communities in the agriculture and agrifood sector: a literature review. Journal of Innovation Economics \& Management 2, 117-142.

Turner KG, Odgaard MV, Bocher PK, Dalgaard T and Svenning JC 2014. Bundling ecosystem services in Denmark: trade-offs and synergies in a cultural landscape. Landscape and Urban Planning 125, 89-104.

van der Werf HGM and Petit J 2002. Evaluation of environmental impact of agriculture at the farm level: a comparison and analysis of 12 indicator-based methods. Agriculture Ecosystems \& Environment 93, 131-145.

Vallejo-Rojas V, Ravera F and Rivera-Ferre MG 2015. Developing an integrated framework to assess agri-food systems and its application in the Ecuadorian Andes. Regional Environmental Change 16, 2171-2185.

Vollet D, Huguenin-Elie O, Martin B and Dumont B 2017. La diversité des services rendus par les territoires d'élevage herbagers fournissant des produits de qualité dans des environnements préservés. INRA Productions Animales 30, 333-350.

Westhoek H, Lesschen JP, Leip A, Rood T, Wagner S, De Marco A, MurphyBokern D, Pallière C, Howard CM, Oenema $O$ and Sutton MA 2015. Nitrogen on the table: the influence of food choices on nitrogen emissions and the European environment. Centre for Ecology \& Hydrology, Edinburgh, UK.

Yrjölä T and Kola J 2008. Cost-benefit analysis of multifunctional agriculture in Finland. Agricultural and Food Science 10, 295-307.

Zehetmeier M, Gandorfer M, Hoffmann H, Muller UK and de Boer IJM 2014. The impact of uncertainties on predicted GHG emissions of dairy cow production systems. Journal of Cleaner Production 73, 116-124.

Zhang W, Ricketts TH, Kremen C, Carney K and Swinton SM 2007. Ecosystem services and dis-services to agriculture. Ecological Economics 64, $253-260$. 